\title{
Nucleic Acid Studies on Halophilic Archaebacteria
}

\author{
By H. N. M. ROSS AND W. D. GRANT* \\ Department of Microbiology, University of Leicester, LE1 $7 R H, U K$
}

(Received 13 July 1984; revised 13 September 1984)

DNA-16S rRNA hybridization studies of archaebacterial halophiles revealed nine major groups. High $(>45 \%)$ DNA-DNA homologies were found only within DNA-rRNA groups. The DNA-DNA homology between the type strains of Halobacterium halobium, Hb. salinarium and $\mathrm{Hb}$. cutirubrum was $>70 \%$. The implications for the taxonomy of the extreme halophiles are discussed.

\section{INTRODUCTION}

Archaebacteria exhibit considerable phylogenetic diversity despite the relatively restricted range of archaebacterial phenotypes. The methanogens comprise three orders (Balch et al., 1979; Wildgruber et al., 1982) and the thermoacidophilic bacteria have been shown to include several major groups probably equivalent to orders (Tu et al., 1982). However, until recently only two major groups of extreme halophiles have been recognized, the rod-shaped or pleomorphic isolates (the halobacteria) and the coccoid isolates (the halococci). The thorough taxonomic studies of Kocur \& Hodgkiss (1973) indicated that all strains of halococci formed a tightly clustered group comprising a monospecific genus with Halococcus morrhuae as the sole species. The halobacteria presently include ten species (Skerman et al., 1980; Soliman \& Trüper, 1982; Rodriguez-Valera et al., 1983; Oren, 1983) and in addition Javor et al. (1982) have suggested the creation of a new genus, Haloarcula, for certain pleomorphic isolates. However, this genus has never been formally proposed and its validity would be in question in view of the similarity of the isolates to certain other halobacteria (Nicholson \& Fox, 1983).

A recent indication of considerable diversity within the halophile phenotype has come with the discovery of the haloalkaliphiles (Tindall et al., 1980, 1984; Ross et al., 1981; Soliman \& Trüper, 1982). This group constitutes a clear, phenotypically distinct group within the general halophile phenotype in that these isolates have an obligate requirement for high $\mathrm{pH}$, and have a very low $\mathrm{Mg}^{2+}$ tolerance (Tindall et al., 1980, 1984; Soliman \& Trüper, 1982). All haloalkaliphilic bacteria isolated to date have ether-linked lipids based both on the universal archaebacterial $\mathrm{C}_{20} \mathrm{C}_{20}$ diether isopranoid core and an asymmetric $\mathrm{C}_{20} \mathrm{C}_{25}$ diether isopranoid core that is not universally present in 'classical' halobacteria (Ross et al., 1981, 1984; De Rosa et al., 1982; Tindall et al., 1984). One isolate has an additional $\mathrm{C}_{25} \mathrm{C}_{25}$ diether isopranoid core lipid (De Rosa et al., 1983). The haloalkaliphilic group includes both rod-shaped and coccoid isolates. Nucleic acid hybridization studies and polar lipid analyses have indicated that the rod-shaped isolates are as distinct from the coccoid isolates as "classical' halobacteria are from "classical" halococci, leading Tindall et al. (1984) to propose the new genera Natronobacterium and Natronococcus for the rods and cocci, respectively.

In the course of this work it was noted that the 'classical' halobacteria $H b$. volcanii and $H b$. halobium appeared as unrelated to each other as each was unrelated to Hc. morrhuae. Earlier, $16 \mathrm{~S}$ rRNA sequence comparisons of these halobacteria had led Fox et al. (1980) to the same conclusions. The polar lipids from a small number of halobacterial isolates have been compared and shown to have some value as taxonomic markers (Evans et al., 1980; Kushwaha et al., 1982) and a more comprehensive investigation of the value of polar lipid analyses in halophile 
taxonomy (Ross et al., 1984) confirmed the similarity of isolates of halococci and pointed again to the differences between $H b$. halobium and $H b$. volcanii. Also revealed by this work were a further six or seven discrete groups of halobacteria equally distinct in terms of their lipid composition, despite, in several instances, identical specific epithets (Ross et al., 1984).

Difficulties in assigning halobacterial isolates to appropriate taxa arise in that 'classical' halobacteria are somewhat biochemically inert and thus phenotypically similar, Although a few isolates are known to utilize certain sugars (Tomlinson \& Hochstein, 1976; Gonzalez et al., 1978; Rodriguez-Valera et al., 1983), in general, standard biochemical tests have not proved very useful in the taxonomy of the group, even when quite extensive numerical taxonomic studies have been carried out (Colwell et al., 1979). Thus there are many isolates residing in culture collections under the same names or simply as Halobacterium sp.

From the preliminary findings of Tindall et al. (1984) and Ross et al. (1984) a considerable diversity may be expected to emerge when more detailed chemotaxonomic analyses are applied to members of this group of phenotypically similar archaebacteria. We present here the results of such a survey and discuss the implications for the taxonomy of the group.

\section{METHODS}

Strains and culture conditions. Details of the test strains and their sources are shown in Table 1. Members of the genera Halobacterium and Halococcus were grown at $37^{\circ} \mathrm{C}$ in the light (Gallenkamp illuminated incubator) in liquid shake culture in the medium of Payne et al. (1960), with the exceptions of Halobacterium saccharovorum, which was grown at $45^{\circ} \mathrm{C}, \mathrm{Hb}$. volcanii, which was grown in the medium of Mullakhanbhai \& Larsen (1975) and $\mathrm{Hb}$. sodomense which was grown in the medium of Oren (1983). Members of the genera Natronobacterium and Natronococcus were grown in the light in the medium of Tindall et al. (1980).

Agar was added to these cultures to a final concentration of $1.8 \%(\mathrm{w} / \mathrm{v})$ for plate cultures. Agar cultures were sealed in Petri dish bags and incubated in the light.

Nucleic acid analyses. (a) DNA-16S rRNA hybridizations were performed using a modification of the procedure of De Ley and De Smedt (1975), as described by Tindall et al. (1984). Hybridizations were carried out overnight in $2.0 \times \mathrm{SSC}\left(\mathrm{NaCl}, 8.7 \mathrm{~g} \mathrm{l}^{-1}\right.$, sodium citrate, $4.41 \mathrm{~g} \mathrm{l}^{-1} ; \mathrm{pH} 7.4$, in $20 \%$ formamide $)$ at $50^{\circ} \mathrm{C}$. Hybrid stability was measured in $1.5 \times$ SSC (in $20 \%$ formamide) in water baths from 55 to $90{ }^{\circ} \mathrm{C}$ in $5{ }^{\circ} \mathrm{C}$ steps. The hybrid melting temperature was determined as the point of $50 \%$ release of label (De Ley \& De Smedt, 1975). Total cellular DNA was used. (b) DNA-DNA reassociations were performed using the S1 nuclease method of Crosa et al.

Table 1. Origins and distinctive features of strains within $16 S$ rRNA homology groups

\begin{tabular}{|c|c|}
\hline $\begin{array}{l}\text { Polar lipid } \\
\text { rRNA } \\
\text { group* }\end{array}$ & Strain \\
\hline 1 & $\begin{array}{l}\text { Hb. cutirubrum CCM } \\
2088 \dagger \\
\text { Hb. halobium CCM } 2090 \dagger \\
\text { Hb. salinarium CCM } \\
2084 \dagger \\
\text { Hh. salinarium CCM } 2148 \\
\text { Hb. salinarium NCMB } 764 \\
\text { Hb. halobium NCMB } 736\end{array}$ \\
\hline 2 & $\begin{array}{l}\text { Hb. halobium NCMB } 777 \\
\text { Hh. salinarium NCMB } 786 \\
\text { Hb. trapanicum NCMB } \\
784\end{array}$ \\
\hline
\end{tabular}

$3 \quad$ Hh. rolcanii NCMB $2012 \dagger$ Hb. mediterranei CCM $3361+$

\section{Distinctive features}

Pleomorphic rods; some strains gas vacuolate; cannot metabolize carbohydrates; Gram-negative; polar lipids: PGP, PGS, PG, GLS.

Rods, some pleomorphic: metabolize certain carbohydrates; non-gas vacuolate; Gram-negative; possess $\mathrm{C}_{26} \mathrm{C}_{25}$ diethers: polar lipids: PGP, PG, PGS, GL.

Coccoid or pleomorphic cells, some strains gas vacuolate; high $\mathrm{Mg}^{2+}$ optima, low $\mathrm{NaCl}$ optima. Some strains grow on single C sources; Gramnegative; polar lipids: PGP, PG, S-DGD, DGD

\section{Origin}

Reference

Salted fish

Petter (1931); Lochhead (1934); Ross et al. (1984).

Salted hides Formisano (1962); Ross et al. (1981, 1984).

Salt ponds; Mullakhanbhai \& Dead Sea Larsen (1975); Rodriguez"Valera et al. (1983); Kushwaha et al. (1982) 
Table 1. (continued)

Polar lipid
rRNA
group*

4

5

6

Hc. morrhuae NCMB

$787 \dagger$

Hc. morrhuae NCMB 761

7

Hb. saccharovorum

NCMB 2081†

Hb. sodomense A TCC

$33755 \dagger$

Hb. trapanicum NRC

$34021+$

8

Hb. marismortui ${ }_{+}^{+}$

Hb. vallismortis ATCC $29715 t$

$9 \quad$ Hb. cutirubrum NCMB 763
Distinctive features

Rods in liquid, cocci on solid media; high $\mathrm{pH}$ optima (9.5), low $\mathrm{Mg}^{2+}$ tolerance; Gramnegative: one strain metabolizes carbohydrates; possess $\mathrm{C}_{20} \mathrm{C}_{25}$ diethers but no glycolipids: polar lipids: PGP, PG.

Cocci; metabolizes

carbohydrates; high $\mathrm{pH}$ optimum (9.5), low $\mathrm{Mg}^{2+}$ tolerance: colonies pale brown; Gram-positive or negative; refractile, non-motile; possess $\mathrm{C}_{20} \mathrm{C}_{25}$ diethers but no glycolipids; polar lipids: PGP, PG.

Cocci; cannot metabolize carbohydrates; cells stable in hypotonic solutions; non-gas vacuolate, refractile, nonmotile; Gram-positive; possess $\mathrm{C}_{20} \mathrm{C}_{25}$ diethers; polar lipids: PGP, PG, TGD-1, S-DGD.

Pleomorphic rods; metabolize numerous carbohydrates; one strain has very high $\mathrm{Mg}^{2+}$ optimum $(0 \cdot 6-1 \cdot 2 \mathrm{M})$; motile; Gram-negative: polar lipids: PGP, PG, PGS, S-DGD.

Highly pleomorphic or plateshaped; some rods; some strains facultatively anaerobic: carbohydrates metabolized: Gram-negative; polar lipids: PGP, PG, PGS, TGD-1.

Rods, highly variable in length; Salted fish some carbohydrates metabolized; coccoid cells in old cultures; Gram-negative; polar lipids: PGP, PG, PGS, TGD-2, S-DGD.
Origin Reference

Saline soda Tindall et al. (1980, lakes 1984); Soliman \& Trüper (1982): Ross $e t$ al. $(1981,1984)$.

Saline soda

Tindall et al. (1984):

Ross (1982): Ross et al. (1984).

Salted fish Kocur \& Hodgkiss (1973): De Rosa et al. (1982): Ross et al. (1984).

Salt pans; Dead Sea Tomlinson \& Hochstein (1976); Ross (1982); Oren (1983).

Salt pools: Gonzalez et al. (1978); Dead Sea Ross (1982); Evans et al. (1980).

Ross (1982); J. Shewan (personal communciation): Ross et al. (1984).

* Polar lipid groups described by Ross \& Grant (1984); rRNA homology groups described in this paper - see Table 2 .

+ Type strain of currently recognized species.

+ This strain resembles the lost strain of $\mathrm{Hb}$. marismortui (Elazari-Volcani, 1957) and was kindly donated by Dr. M. Ginzburg, Jerusalem, Israel.

Abbreviations: Hb., Halobacterum; Hc., Halococcus; Nb., Natronobacterium; Nc., Natronococcus. ATCC, American Type Culture Collection (Maryland USA); CCM, Czechoslovakian Collection of Microorganisms (Brno, Czechoslovakia); DSM, Deutsche Sammlung von Mikroorganismen (Munich, FRG); NCMB, National Collection of Marine Bacteria (Aberdeen, UK).

PG, phosphatidylglycerol; PGP, phosphatidylglycerophosphate; PGS, phosphatidylglycero-sulphate; GLS, glycolipid sulphate: DGD, glycodiosyl diether: S-DGD, sulphated DGD: TGD-1, TGD-2, triglycosyl diethers with different end sugars (Kushwaha et al. 1982); GL, unknown glycolipid.

(1979). Reassociations were done in $200 \mathrm{~mm}-\mathrm{NaCl}$ at $68^{\circ} \mathrm{C}$ (Tindall et al., 1984). Total cellular DNA was used. (c) Plasmids were detected using the alkaline denaturation method of Kado \& Liu (1981). Samples were analysed by agarose gel electrophoresis $(0 \cdot 8 \%, \mathrm{w} / \mathrm{v}) .(d) \mathrm{G}+\mathrm{C}$ content was determined by the buoyant density method of Mandel et al. (1968). 


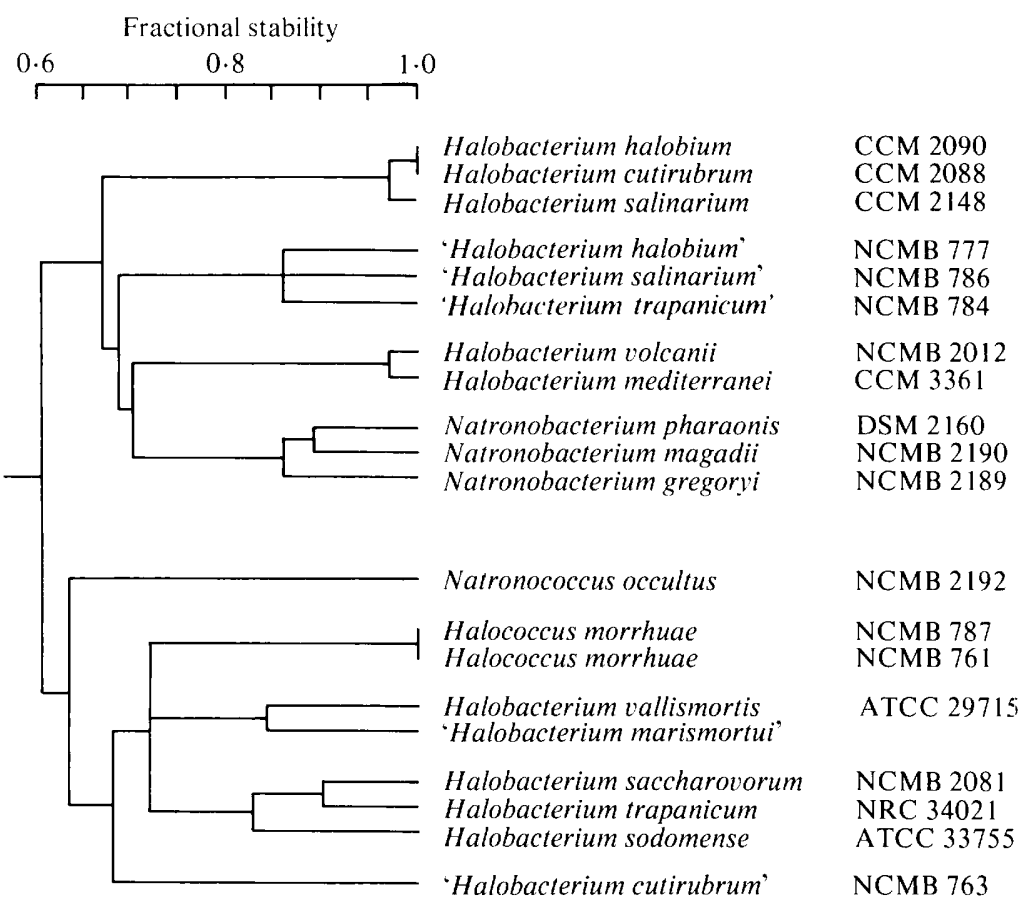

Fig. 1. Relationships amongst extreme halophiles based on DNA/16S rRNA hybrids after Tu et al. (1982).

\section{RESULTS}

DNA-16S RNA hybridizations. Thermal stabilities of DNA-16S rRNA hybrids between different strains and percentage bindings are shown in Table 2 . Homologous hybrids had melting temperatures of between $78^{\circ} \mathrm{C}$ and $80^{\circ} \mathrm{C}$. Stable hybrids were not formed between archaebacterial rRNA and eubacterial DNA under the conditions used. From Table 2 it is possible to construct a dendrogram showing relatedness of strains based on melting temperatures as originally devised by Tu et al. (1982) (Fig. 1). Strains fall into nine distinct groups which follow closely the groups generated from polar lipid pattern analysis (Ross et al., 1984), with the exception of the alkaliphiles, which show very similar polar lipid patterns but split into two separate, unrelated groups on rRNA data (Tindall et al., 1984). Distinctive phenotypic features of strains in each group are shown in Table 1.

DNA-DNA homologies. Homologies between strains are shown in Table 3. High homologies $(>45 \%)$ were seen only between strains within the same 16S rRNA/polar lipid group. Homologies within a $16 \mathrm{~S}$ rRNA group were never lower than $32 \%$, whilst homologies between groups were never higher than $37 \%$ and dropped as low as $12 \%$. Particularly high homologies have already been reported between Natronobacterium pharaonis strains SP1 (NCMB 2191) and DSM $2160(96 \%)$ (Tindall et al., 1984). High homologies were also detected between the type strain $\mathrm{Hb}$. halobium CCM 2090, the type strains of $\mathrm{Hb}$. cutirubrum and $\mathrm{Hb}$. salinarium and various strains named $H b$. halobium, $H b$. cutirubrum and $H b$. salinarium $(>60 \%)$, in agreement with early studies on a limited number of strains by Moore \& McCarthy (1969). The two Halococcus morrhuae strains tested showed a similar high degree of homology with each other.

$G+C$ and plasmid contents. $\mathrm{G}+\mathrm{C}$ contents of strains are given in Table 4 . It can be seen that the majority of the strains possess both main band DNA and substantial amounts of satellite DNA. Those strains which showed satellite bands in $\mathrm{CsCl}$ gradients also possessed plasmids when the analytical procedure of Kado \& Liu (1981) was applied, with the exception of $H b$. 


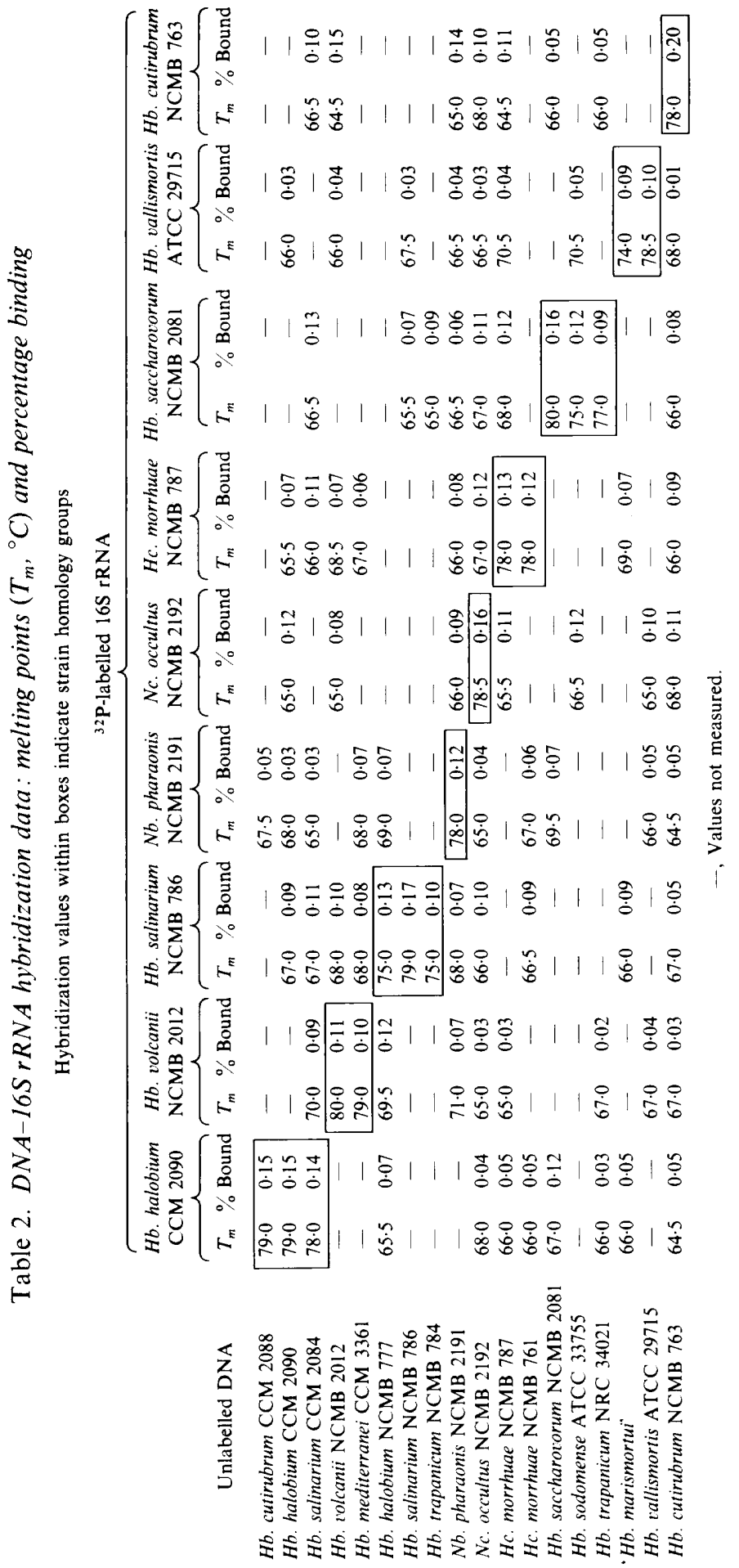


Table 3. DNA homologies amongst archaebacterial halophiles

Unlabelled DNA

\begin{tabular}{|c|c|c|c|c|c|c|}
\hline \multicolumn{7}{|c|}{${ }^{3} \mathrm{H}$-labelled DNA } \\
\hline 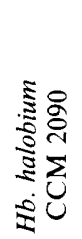 & 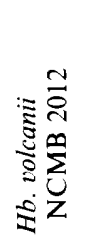 & 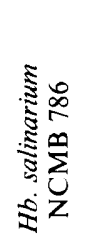 & 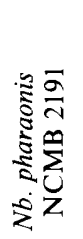 & 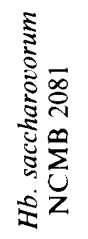 & 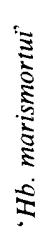 & 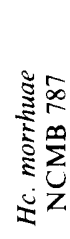 \\
\hline
\end{tabular}

Hb. cutirubrum CCM 2088

Hb. halobium CCM 2090

Hb. halobium NCMB $736+$

Hb. salinarium CCM 2084

Hb. salinarium CCM $2148 \dagger$

Hb. salinarium NCMB $764 \dagger$

Hb. mediterranei CCM 3361

Hb. volcanii NCMB 2012

Hb. halobium NCMB 777

Hb. salinarium NCMB 786

Hb. trapanicum NCMB 784

Nb. pharaonis NCMB 2191

Nc. occultus NCMB 2192

Hb. saccharovorum NCMB 2081

Hb. sodomense ATCC 33755

Hb. trapanicum NRC 34021

'Hb. marismortui'

Hb. vallismortis A TCC 29715

Hc. morrhuae NCMB 787

Hc. morrhuae NCMB 761

Hb. cutirubrum NCMB 763

$\begin{array}{lcc}81 & 31 & - \\ 100^{*} & 33^{*} & - \\ 76 & 25 & - \\ 72 & 31 & - \\ 60 & - & - \\ 77 & 31 & - \\ 31 & 38 & - \\ 35^{*} & 100^{*} & - \\ 33 & 35 & 50 \\ 31 & 26 & 100 \\ 23 & 13 & 52 \\ 35^{*} & 32^{*} & - \\ 22 & 12^{*} & - \\ 36 & 22 & - \\ - & - & - \\ - & - & - \\ 38 & 35 & - \\ 31 & 31 & - \\ 34^{*} & 32^{*} & - \\ 26 & - & - \\ 29 & 34 & -\end{array}$

$\begin{array}{cccc}34 & 29 & - & 34 \\ 35^{*} & 30 & - & 32^{*} \\ 35 & 25 & - & 34 \\ 33 & - & - & - \\ - & 24 & - & 32 \\ 34 & 33 & - & 22 \\ 30 & 27 & - & 25 \\ 32^{*} & 31 & - & 21^{*} \\ 24 & 33 & - & 32 \\ 32 & 31 & - & 26 \\ 31 & 20 & - & 27 \\ 100^{*} & 30 & - & 35^{*} \\ 16^{*} & 22 & - & 25 \\ 33 & 100 & - & 30 \\ - & 45 & - & - \\ -33 & 52 & - & - \\ 33 & 30 & 100 & 24 \\ 35 & 23 & 39 & 36 \\ 31^{*} & 12 & - & 100^{*} \\ 30 & - & - & 76 \\ 34 & 25 & - & 25\end{array}$

_, Values not determined.

* Values quoted by Tindall et al. (1984).

+ Strains not included in DNBA-16S rRNA hybridization data.

Table 4. Plasmid and $G+C$ content of halophilic archaebacteria

\begin{tabular}{lccc}
\multicolumn{1}{c}{ Strain } & $\begin{array}{c}\text { Approx. size } \\
\text { of plasmid } \\
(\mathrm{kbp})\end{array}$ & $\begin{array}{c}\text { Major } \\
\text { component }\end{array}$ & $\begin{array}{c}\text { Minor } \\
\text { component }\end{array}$ \\
Hb. cutirubrum NCMB 763 & 144 & $67 \cdot 1$ & $57 \cdot 8$ \\
Hb. halobium CCM 2090* & $144 \dagger$ & $70 \cdot 9$ & $59 \cdot 2$ \\
'Hb. marismortui & - & $61 \cdot 9$ & $54 \cdot 7$ \\
Hb. mediterranei CCM 3361 & - & $62 \cdot 2$ & - \\
Hb. saccharovorum NCMB 2081 & - & $71 \cdot 2$ & - \\
Hb. salinarium NCMB 786 & 144 & $69 \cdot 9$ & $60 \cdot 0$ \\
Hb. sodomense ATCC 33755 & - & $67 \cdot 4$ & - \\
Hb. vallismortis ATCC 29715 & - & $64 \cdot 7$ & - \\
Hb. volcanii NCMB 2012* & $90,6 \dagger$ & $66 \cdot 5$ & $55 \cdot 3$ \\
Hb. trapanicum NRC 34021 & $90,6 \dagger$ & $64 \cdot 3$ & - \\
Hc. morrhuae NCMB 787 & ND & $64 \cdot 6$ & $53 \cdot 4$ \\
Nb. pharaonis NCMB 2191* & 144 & $62 \cdot 1$ & $51 \cdot 4$ \\
Nc. occultus NCMB 2192* & 144 & $64 \cdot 0$ & $55 \cdot 7$
\end{tabular}

ND, Not detectable by method of DNA extraction.

* Strains and values quoted by Tindall et al. (1984).

† Values quoted by Pfeifer et al. (1981). 
marismortui, for which no plasmid was detected. This correlates well with data published by Tindall et al. (1984) for a smaller number of strains.

\section{DISCUSSION}

It is clear from these studies that the genetic diversity of the extremely halophilic archaebacteria is considerable, despite relatively narrow phenotypic variation. The nine groups defined by DNA-16S rRNA hybridization data are likely to be at supra-specific level (De Smedt \& De Ley, 1977; Stackebrandt et al., 1981). The results presented here support the idea of Halococcus as a monospecific genus. Within the genus Halobacterium, the type strains $H b$. salinarium CCM 2084, Hb. halobium CCM 2090 and Hb.cutirubrum CCM 2088 show high DNA homologies with each other (Table 2 ) and probably should be considered different isolates of the same species. These type strains have at various other times been considered identical (Gibbons, 1974; Colwell et al., 1979). Most other strains examined and originally described as Halohacterium sp. fall into other quite distinct rRNA homology groupings. In all cases the groupings have distinct polar lipid patterns (Ross et al., 1984), with the exception of the haloalkaliphilic genera Natronobacterium and Natronococcus, which show very similar patterns and yet appear only distantly related to each other and the other halophiles (Tindall et al., 1984; Ross et al., 1984) (Fig. 1). The diether core lipid composition of all strains within each group is identical (Ross et al., 1984).

Phenotypic differences between DNA-rRNA homology groups are in most cases not clear cut (Table 1). Environmental pressures in the extreme conditions of salt pans and soda lakes may limit variety in biochemical and physiological processes, reflected in relative biochemical inactivity in most strains examined (Colwell et al., 1979; Gibbons, 1974). Some phenotypic differences do exist between the RNA homology groups, as can be seen in Table 1, although the number of biochemical traits is small and a greater divergence may emerge as more biochemical data is accumulated.

DNA homologies between strains within rRNA homology groups are $>32 \%$ but high DNA homologies also exist between strains from different rRNA homology groups (Table 3 ). Sapienza \& Doolittle (1982) have shown the presence of large numbers of repeat sequences in the genomes of $\mathrm{Hb}$. halobium and $\mathrm{Hb}$. volcanii, some of which are common to both species. This would significantly increase the homology between strains even though they lie in different rRNA homology groups. If these repeat sequences are present in all extreme halophiles, overall DNA homologies may be higher than expected. Additionally, the reassociations were performed at the optimal hybridization temperature which allows partial sequence homologies to be measured giving higher overall values (Garvie et al., 1981). The presence of similar-sized plasmids in most strains may also produce further sequence homology between apparently unrelated strains. Furthermore, Pfeifer et al. (1981) have shown that extensive plasmid sequences can be found in the chromosomal DNA of strains that do not possess plasrnids. The interpretation of DNA-DNA homology studies, whether the cross-matching of plasmidbearing strains, non plasmid-bearing strains or plasmid and non plasmid-bearing strains, must thus be treated with caution. DNA-rRNA hybridization studies performed with total DNA are not subject to the same problems of interpretation. We believe that it is significant that high homologies $(>45 \%)$ are to be seen only within DNA-rRNA groups.

Given the proposal of the two genera Natronococcus and Natronobacterium (Tindall et al., 1984), then the other rRNA groups shown here are probably of equivalent taxonomic rank. The results presented here agree well with groups obtained by $5 \mathrm{~S}$ rRNA sequence comparisons of these strains (G. E. Fox, personal communication). Groupings at suprageneric level are uncertain using DNA-rRNA hybridization data and detailed 16S rRNA oligonucleotide cataloguing will be necessary for such definition. A new taxonomy for the archaebacterial halophiles comparable in depth to those taxonomies currently accepted for the other archaebacteria is overdue.

We are grateful to Dr G. E. Fox for invaluable advice during the compilation of this paper. H. N. M. R. acknowledges with thanks the award of an SERC research studentship. 


\section{REFERENCES}

Balch, W. E., Fox, G. E., Magrum, L. J., Woese, C. R. \& Wolfe, R. S. (1979). Methanogens: reevaluation of a unique biological group. Microbiological Reriews 43(2), 260-296.

Colwell, R. R., Litchfield, C. D., VReeland, R. H., Kiefer, L. A. \& GibBons, N. E. (1979). Taxonomic studies of red halophilic bacteria. International Journal of Systematic Bacteriology 29, 379-399.

Crosa, J. H., Williams, B. L., Jorgensen, J. J. \& Evans, C. A. (1979). Comparative study of deoxyribonucleic acid homology and physiological characteristics of Peptococcus saccharolyticus. International Journal of Systematic Bacteriology 29, 328-332.

DE LEY, J. \& DE SMEDT, J. (1975). Improvements of the membrane filter method for DNA-rRNA hybridization. Antonie van Leeuwenhoek 36, 287-307.

De Rosa, M., Gambacorta, A., Nicolaus, B., Ross, H. N. M., Grant, W. D. \& Bu'lock, J. D. (1982). An asymmetric archaebacterial diether lipid from alkaliphilic halophiles. Journal of General Microbiology 128, 343-348.

De Rosa, M., Gambacorta, A., Nicolaus, B. \& Grant, W. D. (1983). A $\mathrm{C}_{25} \mathrm{C}_{25}$ diether core lipid from archaebacterial haloalkaliphiles. Journal of General Microbiology 129, 2333-2337.

De SMEdT, J. \& DE Ley, J. (1977). Intra- and intergeneric similarities of Agrobacterium ribosomal ribonucleic acid cistrons. International Journal of Systematic Bacteriology 27, 222-240,

Elazari-VolCani, B. (1957). The genus Halobacterium. In Bergey's Manual of Determinative Bacteriology, 7th edn, pp. 207-212. Edited by R. S. Breed, E. G. D. Murray \& N. R. Smith. Baltimore: Williams \& Wilkins.

Evans, R. W., Kushwaha, S. C. \& Kates, M. (1980). The lipids of Halobacterium marismortui, and extremely halophilic bacterium from the Dead Sea. Biochimica et biophysica acta 619, 533-544.

Formisano, M. (1962). Richerche sul "calore rosso" della pelli salate: II. Isolamento e caratterizzazione degli agent microbici causant l'alterazione. Bolletini della $R$. Stazione sperimentale per l'industria delle Pelli e delle materie concianti 38, 183-213.

Fox, G. E., Stackebrandt, E., Hespell, R. B., Gibbon, J., Maniloff, J., Dyer, T. A., Wolfe, R. S., Balch, W. E., TANner, R. S., Magrum, L. J., Sablen, L. B., Blakemore, R., Gupta, R., Bonen, L., Lewis, B. J., Stahl, D. A., Luehrsen, K. R., Chen, K. N. \& Woese, C. R. (1980). The phylogeny of prokaryotes. Science 209, 457-463.

Garvie, E. I., Farrow, J. A. E. \& Phillips, B. A. (1981). A taxonomic study of some strains of streptococci which grow at $10{ }^{\circ} \mathrm{C}$ but not at $45^{\circ} \mathrm{C}$ including Streptococcus lactis and Streptococcus cremoris. Zentralblatt für Bakteriologie und Hygiene (Abteilung Originale C) 2, 151-165.

GibBons, N. E. (1974). The family Halobacteriaceae. In Bergey's Manual of Determinative Bacteriology, 8th edn, pp. 269-272. Edited by R. E. Buchanan \& N. E. Gibbons. Baltimore: Williams \& Wilkins.

Gonzalez, C., Gutierrez, C. \& Ramirez, C. (1978). Halobacterium vallismortis sp. nov. An amylolytic and carbohydrate-metabolizing, extremely halophilic bacterium. Canadian Journal of Microbiology 24, 710-715.
Javor, B., Requadt, C. \& Stoeckenius, W. (1982). Box-shaped halophilic bacteria. Journal of Bacteriology 151, 1532-1542.

KADO, C. I. \& LIU, S.-T. (1981). Rapid procedure for detection and isolation of large and small plasmids. Journal of Bacteriology 145, 1365-1373.

Kocur, M. \& HodGKISs, W. (1973). Taxonomic status of the genus Halococcus Schoop. International Journal of Systematic Bacteriology 23, 151-156.

Kushwaha, S. C., Kates, M., Juez, G., RodriguezVAlera, F. \& Kushner, D. J. (1982). Polar lipids of an extremely halophilic strain (R4) isolated from salt pans in Spain. Biochimica et biophysicaacta 711, 19-25.

LochHEAD, A. G. (1934). Bacteriological studies on the red discolouration of salted hides. Canadian Journal of Research 10, 275-286.

Mandel, M., Schildkraut, C. L. \& Marmur, J. (1968). Use of $\mathrm{CsCl}$ density gradient analysis for determining the guanine plus cytosine content of DNA. Methods in Enzymology 76, 184-195.

MOORE, R. L. \& McCARTHY, B. J. (1969). Base sequence homology and renaturation studies of the deoxyribonucleic acid of extremely halophilic bacteria. Journal of Bacteriology 99, 255-262.

Mullakhanbhai, M. F. \& Larsen, H. (1975). Halobacterium volcanii spec. nov., a Dead Sea Halobacterium with a moderate salt requirement. Archives of Microbiology 104, 207-214.

Nicholson, D. E. \& Fox, G. E. (1983). Molecular evidence for a close phylogenetic relationship between box-shaped halophilic bacteria, Halobacterium vallismortis and Halobacterium marismortui. Canadian Journal of Microbiology 29, 52-60.

Oren, A. (1983). Halobacterium sodomense sp. nov. a Dead Sea Halobacterium with an extremely high magnesium requirement. International Journal of Systematic Bacteriology 33, 381-386.

Payne, J. I., Sehgal, S. N. \& Gibbons, N. E. (1960). Immersion refractometry of some halophilic bacteria. Canadian Journal of Microbiology 6, 9-15.

PetTer, H. F. M. (1931). On bacteria of salted fish. Proceedings of the Academy of Science (Amsterdam) 34, 1417-1423.

Pfeifer, F., Weidinger, G. \& Goebel, W. (1981). Characterization of plasmids in halobacteria. Journal of Bacteriology 145, 369-374.

Rodriguez-Valera, F., Juez, G. \& Kushner, D. J. (1983). Halobacterium mediterranei spec. nov., a new carbohydrate-utilizing extreme halophile. Systematic and Applied Microbiology 4, 369-381.

Ross, H. N. M. (1982). The extremely halophilic archaebacteria. PhD thesis, Leicester University, UK.

Ross, H. N. M., Collins, M. D., Tindall, B. J. \& Grant, W. D. (1981). A rapid procedure for the detection of archaebacterial lipids in halophilic bacteria. Journal of General Microbiology 123, 75-80.

Ross, H. N. M., Grant, W. D. \& Harris, J. E. (1984). Lipids in Archaebacterial Taxonomy. In Chemical Methods in Bacterial Systematics. Edited by M. Goodfellow \& D. E. Minnikin, New York: Academic Press (In the Press).

Sapienza, C. \& Doolittle, W. F. (1982). Unusual physical organization of the Halobacterium genome. Nature, London 295, 384-389. 
Skerman, V. B. D., McGowan, V. \& Sneath, P. H. A. (eds) (1980). Approved Lists of Bacterial Names. International Journal of Systematic Bacteriology 30(1), 225-420.

Soliman, G. S. H.\& Truper, H. G. (1982). Halobacterium pharaonis sp. nov., a new extremely haloalkaliphilic archaebacterium with low magnesium requirement. Zentralblatt für Bakteriologie und Hygiene (Abteilung Originale C) 3, 318-329.

Stackebrandt, E., WunNer-Fussl, B., Fowler, V. \& SCHLEIFER, K. H. (1981). Deoxyribonucleic acid homologies and ribonucleic acid similarities among spore-forming members of the order Actinomycetales. International Journal of Systematic Bacteriology $31,420-431$.

Tindall, B. J., Mills, A. A. \& Grant, W. D. (1980). An alkalophilic red halophilic bacterium with a low magnesium requirement from a Kenyan soda lake. Journal of General Microbiology 116, 257-260.
Tindall, B. J., Ross, H. N. M. \& Grant, W. D (1984). Natronobacterium gen. nov. and Natronococcus gen. nov., two new genera of haloalkaliphilic archaebacteria. Systematic and Applied Microbiology 5, 41-57.

Tomlinson, G. A. \& Hochstein, L. I. (1976). Halobacterium saccharovorum sp. nov., a carbohydrate-metabolizing, extremely halophilic bacterium. Canadian Journal of Microbiology 22, 587-591.

Tu, J., Prangishvilli, D., Huber, H., Wildgruber, G., ZILliG, W. \& STETTER, K. O. (1982). Taxonomic relations between archaebacteria including 6 novel genera examined by cross hybridization of DNAs and 16S RNAs. Journal of Molecular Evolution 18, $109-114$

Wildgruber, G., Thomm, M., Konig, H., Ober, K., Ricchiuto, T. H. \& Stetter, K. O. (1982) Methanoplanus limicola, a plate shaped methanogen representing a novel family, the Methanoplanaceae. Archives of Microbiology 132, 31-36. 